\title{
Evaluasi dan Pemetaan Minat Studi Siswa SMA dan SMK di Kota Bogor Pada Program Studi Ekonomi Syariah
}

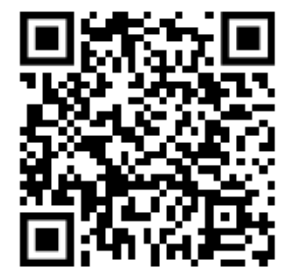

Yulia Nurendah¹, Mumuh Mulyana², Muanas³

\begin{abstract}
Abstrak
Perkembangan ekonomi syariah beberapa dekade ini menunjukkan arah yang positif di tengah gejolak ekonomi dunia yang rentan terhadap krisis. Ekonomi syariah dipandang sebagai sebuah sistem ekonomi alternatif dan solusi untuk menyelesaikan permasalahan ekonomi dunia yang tidak terguncang akibat krisis yang terjadi di dunia. Perkembangan tersebut, baik di Indonesia maupun di dunia, mendorong permintaan terhadap tenaga-tenaga ahli di bidang ekonomi syariah semakin tinggi. Penelitian ini memiliki tujuan untuk: 1) Untuk mengetahui brand knowledge siswa SMA dan SMK di Kota Bogor tentang STIE Kesatuan sebaagi penyelenggara Prodi Ekonomi Syariah. 2) Untuk mengetahui minat, pilihan, alasan dan harapan siswa SMA dan SMK di Kota Bogor untuk melanjutkan studi pada Program Studi Ekonomi Syariah. Adapun hasil analisis dan pembahasannya sebagai berikut : 1) Mayoritas responden mengetahui tentang STIE Kesatuan sebagai sebuah perguruan tinggi yang bagus. STIE Kesatuan sangat dikenal. Hal tersebut didukung oleh brand image STIE Kesatuan, sebagai kampus yang memiliki keunggulan memiliki jaringan yang luas, reputasi yang baik, dan lulusan yang berkompeten. 2) Minat siswa SMA dan SMK di Kota Bogor untuk melanjutkan studi sangat tinggi. Alasan yang dikemukakan apabila tidak ingin melanjutkan adalah karena responden ingin bekerja terlebih dahulu dan tidak ada biaya,. 3) Minat responden siswa SMA dan SMK di Kota Bogor untuk melanjutkan studi sangat tinggi. 4) Jenjang pendidikan yang dipilih siswa SMA dan SMK di Kota Bogor untuk melanjutkan studi mayoritas pada jenjang sarjana. 5) Mayoritas responden siswa SMA dan SMK di Kota Bogor, mengetahui tentang jurusan ekonomi syariah. 6) Alasan yang melandasi siswa SMA dan SMK memilih Program Studi Ekonomi Syariah ingin mengetahui bagaimana sebuah sistem ekonomi ditata secara syariah. 7) Mayoritas responden siswa SMA dan SMK di Kota Bogor, mengetahui bahwa Institut Pertanian Bogor memiliki program studi ekonomi syariah. 8) Mayoritas responden siswa SMA dan SMK di Kota Bogor, memilih Universitas Indonesia dan Institut Pertanian Bogor sebagai perguruan tinggi dengan program studi ekonomi syariah yang paling diminati. 9) Mayoritas responden siswa SMA dan SMK di Kota Bogor, tidak tahu dan tidak tertarik untuk melanjutkan ke jurusan ekonomi syariah. Adapun dasar yang melandasi responden mayoritas menjawab tidak tahu dan menjawab tidak tertarik adalah berkenaan dengan biaya, dimana mereka memiliki keterbatasan biaya. Selain itu karena adanya keinginan untuk segera berkerja. 10) Harapan yang diinginkan Siswa SMA dan SMK ketika diterima/berkuliah di Program Studi Ekonomi Syariah di STIE Kesatuan ebih banyak pada keinginan responden untuk mendapatkan ilmu dan pengalaman serta keinginan untuk segera lulus dan dapat bekerja.
\end{abstract}

Kata Kunci: program studi, ekonomi syariah, perguruan tinggi
Program Studi Manajemen Pemasaran, STIE Kesatuan ogor, Jl,. Ranggagading No 1, Bogor, Jawa Barat, Indonesia

Program Studi Akuntansi, STIE Kesatuan, Jl.

Ranggagaading No 1 ogor, Jawa Barat, Indonesia.

* Email of Corresponding Author : lia_niceone@yahoo.com

Submitted: Januari 2018

Accepted : Desember 2018

JAS-PT

JURNAL ANALISIS SISTEM PENDIDIKAN TINGGI

ISSN 2580 - 5339

eISSN $2620-5718$

Volume 2

Nomor 2

DESEMBER 2018

Hal $83-94$

FORUM DOSEN INDONESIA 


\section{Pendahuluan}

Perkembangan ekonomi syariah beberapa dekade ini menunjukkan arah yang positif di tengah gejolak ekonomi dunia yang rentan terhadap krisis. Ekonomi syariah dipandang sebagai sebuah sistem ekonomi yang tidak terguncang akibat krisis yang terjadi di dunia. Ekonomi syariah dinilai sebagai sebuah alternatif dan solusi untuk menyelesaikan permasalahan ekonomi dunia.

Fenomena ekonomi syariah terjadi bukan hanya di negara-negara muslim atau negara yang mayoritas penduduknya beragama Islam, namun wacana sistem ekonomi syariah juga ramai diperbincangkan di negara-negara yang penduduk muslimnya tergolong minoritas, seperti Australia, Belanda, Inggris, dan lain-lain. Wacana penerapan system ekonomi syariah telah berlangsung sejak negara-negara OKI membentuk suatu lembaga dengan nama Islamic Development Bank (IDB), bahkan jauh sebelum itu.

Bahkan, sebagaimana diketahui saat ini Inggris telah mengklaim bahwa negaranya telah berhasil menerapkan sistem ekonomi syariah. Selain itu Singapura juga mengklaim negaranya sukses menerapkan sistem ekonomi syariah, bahkan telah menjadi pusat keuangan syariah di dunia. Padahal banyak negara-negara muslim yang sudah lama menerapkan sistem ekonomi syariah belum berani mengklaim dirinya 'sukses'.

Sebagai negara dengan jumlah penduduk muslim terbesar di dunia, potensi keuangan syariah di Indonesia juga senantiasa disebut terbesar dibandingkan dengan negara lain. Meskipun pada kenyataannya, keuangan syariah, baik pasar modal syariah, perbankan syariah, maupun asuransi syariah di Indonesia masih belum berkembang pesat. Meskipun lambat, potensi Indonesia sebagai kiblat keuangan syariah dunia masih diyakini oleh pelaku industri baik dalam negeri maupun luar negeri.

Sehubungan dengan berkembangnya sistem ekonomi syariah, baik di Indonesia maupun di dunia, permintaan terhadap tenaga-tenaga ahli dibidang ekonomi syariahpun semakin tinggi. Oleh karena itu ekonomi syariah juga mulai berkembang pada sektor pendidikan.

Perguruan tinggi sebagai agen perubahan (agent of change) merupakan wadah dimana harapan lahirnya sumber daya manusia yang memiliki kompetensi dan keahlian yang dibutuhkan oleh dunia kerja. Profesionalisme dan mental spiritual yang baik menjadi daya dukung utama dalam menjawab tantangan dunia kerja saat ini dan di masa yang akan datang. Perguruan Tinggi diharapkan mampu menjawab kebutuhan sumber daya manusia untuk segala bidang ilmu dalam tataran normative maupun pragmatis, termasuk bidang ekonomi syariah.

Berdasarkan informasi yang dikutip dari http://www.fshuinsgd.ac.id/ yang diakses pada tanggal 13 Juni 2018, dipaparkan bahwa, secara nasional untuk kurun waktu lima tahun dibutuhkan lulusan ekonomi syariah, dari mulai jenjang D3 sampai S3, sebanyak 39.000 orang. Sepuluh tahun ke depan dibutuhkan 125.000 orang. Bahkan, kebutuhan bisa lebih dari jumlah itu mengingat peluang lulusan ekonomi syariah sangat diperlukan oleh berbagai lembaga nonbank, lembaga keuangan syariah seperti pasar modal, asuransi, koperasi, akuntan publik, dan lembaga-lembaga umum lainnya

JAS-PT

JURNAL ANALISIS SISTEM PENDIDIKAN TINGG ISSN $2580-5339$ eISSN $2620-5718$

Volume 2

Nomor 2

DESEMBER 2018

Hal $83-94$

FORUM DOSEN INDONESIA
Keseluruhan hal tersebut merupakan potensi pasar yang besar untuk perguruan tinggi. Tidak dipungkiri, sebagian perguruan tinggi memiliki program studi atau jurusan yang sudah tidak diminati lagi. Selain itu terdapat perguruan tinggi yang belum memiliki program studi yang memiliki potensi besar dalam pangsa pasarnya (diminati oleh masyarakat). Banyak faktor yang menyebabkan hal tersebut. Untuk mengantisipasi, perubahan minat calon mahasiswa terhadap program studi tertentu, dibutuhkan suatu 
penelaahan dan penelitian yang mendalam tentang berbagai hal yang menjadi penyebabnya.

\section{KAJIAN TEORI}

\section{Pengertian dan Ruang Lingkup Ekonomi Syariah}

Ekonomi syariah sebagai sebuah sistem ekonomi sudah dikenal sejak lama. Ekonomi syariah berlaku universal untuk semua orang. Sistem ekonomi syariah memiliki nilainilai dan norma-norma universal yang dapat dijalankan dan diterima oleh semua kalangan,.

Ekonomi syariah merupakan sistem ekonomi yang berbasis pada Al Qur'an dan sunnah. Tujuan dari ekonomi syariah adalah mensejahterakan masyrakat. (www.ekonomisyariah.org diakses tanggal 11 April 2018). Menurut www.wikipedia.com (diakses tanggal 11 April 2018) Ekonomi syariah merupakan ilmu pengetahuan sosial yang mempelajari masalah-masalah ekonomi rakyat yang diilhami oleh nilai-nilai Islam. Ekonomi syariah merupakan sistem dan aktifitas ekonomi yang didasarkan pada prinsip-prinsip syariat Islam (www.asianbrainhippo.com diakses tanggal 11 April 2018)

Bila memperhatikan Undang-undang Peradilan Agama No. 7 Tahun 1989, maka dapat diketahui bahwa ruang lingkup ekonomi syariah meliputi : Bank syariah, asuransi syariah, lembaga keuangan mikro syariah, reasuransi syariah, obligasi syariah, surat berjangka menengah syariah, reksadana syariah, sekuritas syariah, pegadaian syariah, pembiayaan syariah, dana pensiun lembaga keuangan syariah dan bisnis syariah.

Penerapan ekonomi syariah di masyarakat terbagi diberbagai bisnis, diantaranya perbankan syariah, asuransi syariah, pasar modal syariah, pegadaian syariah, multi finance syariah, koperasi syariah, dan lain sebagainya. Di samping nilai universalnya, kelebihan ekonomi syariah adalah adanya prinsip untuk memberdayakan masyarakat, perusahaan tidak hanya didorong untuk mengambil keuntungan secara benar, halal, dan tanpa merugikan pihak lain, namun perusahaan juga memiliki kewajiban membiayai zakat untuk kepentingan sosial. Dengan demikian, sebagian keuntungan yang didapat perusahaan harus dialokasikan untuk kepentingan fakir miskin dan orangorang yang membutuhkan bantuan. (www.asianbrainhippo.com diakses tanggal 11 April 2018).

\section{Program Studi Ekonomi Syariah}

Program studi ekonomi syariah merupakan program pendidikan yang mempersiapkan mahasiswa menjadi ahli dibidang ekonomi syariah. Dimana dalam hal ini, dengan program studi ekonomi syariah diharapkan dapat mewujudkan lulusan yang mempunyai ilmu pengetahuan tentang ekonomi syariah, soft skill, dan live skill yang memenuhi standar kebutuhan lapangan kerja di bidang syariah. (http://www.ipb.ac.id diunduh 11 April 2018)

\section{METODE PENELITIAN}

Penelitian ini akan dilaksanakan pada beberapa Sekolah di Kota Bogor baik SMA maupun SMK (Negeri dan Swasta). Desain Penelitian yang digunakan dalam penelitian ini adalah deskriptif. Metode penelitian yang dilakukan adalah survey dengan studi secara mendalam (depth-study).

JAS-PT

JURNAL ANALISIS SISTEM PENDIDIKAN TINGG ISSN $2580-5339$ elSSN $2620-5718$

Volume 2 Nomor 2 Desember 2018 Hal $83-94$

FORUM DOSEN INDONESIA 
Jenis data pada penelitian ini adalah data primer, dikarenakan data secara langsung diperoleh oleh peneliti pada narasumber. Sumber data adalah para Siswa SMA dan SMK kelas 3 di Kota Bogor, yang terpilih sebagai sampel penelitian. Populasi penelitian ini adalah seluruh siswa Kelas 3 pada SMA dan SMK di Kota Bogor. Sampel penelitian ditetapkan dengan metode non acak secara kebetulan, yakni metode convenience. Metode pengumpulan data yang digunakan pada penelitian ini adalah menggunakan bantuan instrumen berupa angket atau kuesioner.

Untuk mengetahui ada tidaknya asosasi antara karakteristik responden dengan variabel tertentu. Uji Chi Square berguna untuk menguji hubungan atau pengaruh dua buah variabel nominal dan mengukur kuatnya hubungan antara variabel yang satu dengan variabel nominal lainnya.

$$
\begin{aligned}
& \chi_{p}^{2}=\sum_{i j} \frac{\left(f_{i j}-E_{i j}\right)^{2}}{E_{i j}} \\
& \text { Di mana: } \\
& \text { Fij = Frekuensi observasi } \\
& \text { Eij = Nilai harapan }
\end{aligned}
$$

\section{HASIL DAN PEMBAHASAN}

\section{Pengetahuan Siswa SMA dan SMK di Kota Bogor tentang STIE Kesatuan}

Berdasarkan Gambar 1 tersebut, diperoleh diketahui sebanyak $478(46,7 \%)$ responden menyatakan setuju mengetahui STIE Kesatuan, sebanyak 251 (24,5\%) responden menyatakan sangat setuju mengetahui STIE Kesatuan, sebanyak $237(23,1 \%)$ responden menyatakan netral mengetahui STIE Kesatuan, sedangkan sisanya sebanyak $45(4,4 \%)$ responden menyatakan tidak setuju mengetahui STIE Kesatuan dan sebanyak $12(1,2 \%)$ responden menyatakan sangat tidak setuju mengetahui STIE Kesatuan.

JAS-PT

JURNAL ANALISIS SISTEM PENDIDIKAN TINGG

ISSN $2580-5339$

eISSN $2620-5718$

Volume 2

Nomor 2

DESEMBER 2018

Hal $83-94$

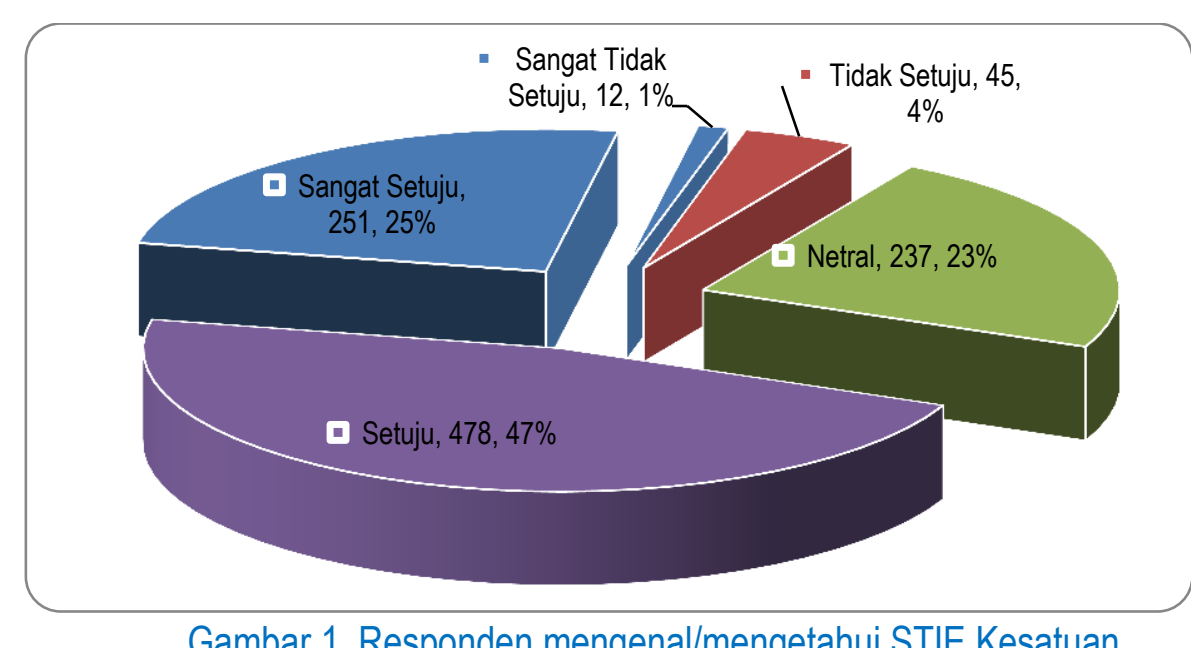

Gambar 1. Responden mengenal/mengetahui STIE Kesatuan

Mayoritas responden mengetahui tentang STIE Kesatuan sebagai sebuah perguruan tinggi yang bagus. STIE Kesatuan sangat dikenal. Hal ini tercermin dari brand awarness sebagaimana yang terlihat pada Gambar 2 berikut ini. 


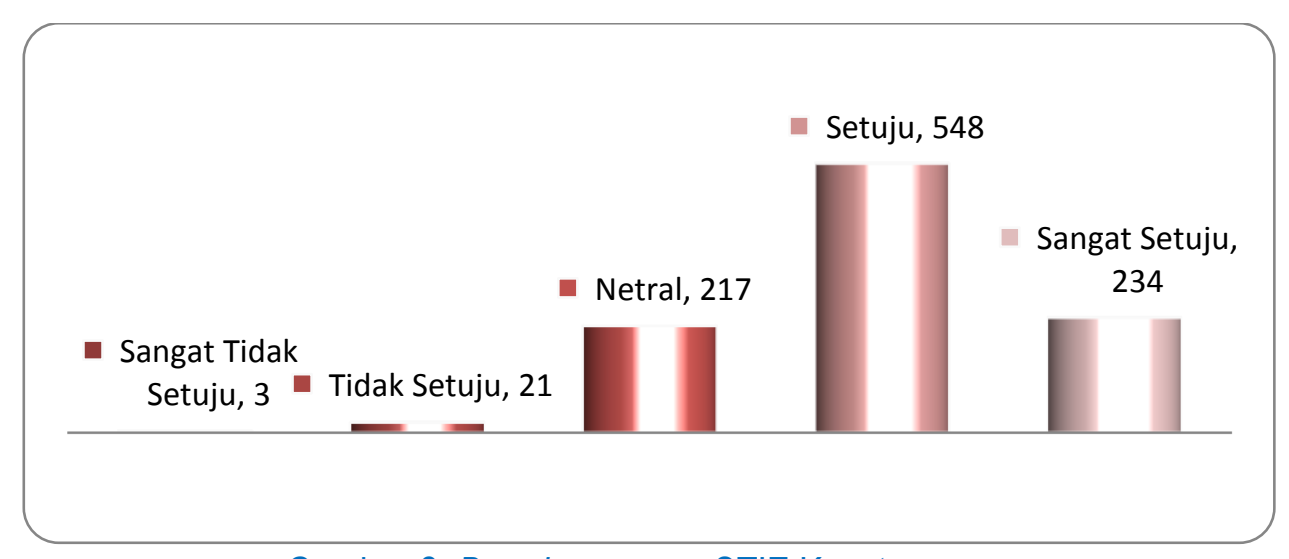

Gambar 2. Brand awarness STIE Kesatuan

Berdasarkan Gambar 2 tersebut di atas dapat diketahui sebanyak 548 (53,5 \%) responden menyatakan setuju mengenal STIE Kesatuan, sebanyak 234 (22,9 \%) responden menyatakan sangat setuju mengenal STIE Kesatuan, sebanyak 217 (21,2 $\%$ ) responden menyatakan netral mengenal STIE Kesatuan, sedangkan sisanya sebanyak $21(2,1 \%)$ responden menyatakan tidak setuju mengenal STIE Kesatuan dan sebanyak $3(0,3 \%)$ responden menyatakan sangat tidak setuju mengenal STIE Kesatuan

Brand awareness STIE Kesatuan adalah kemampuan calon mahasiswa untuk mengenali maupun mengingat nama STIE Kesatuan sebagai salah satu perguruan tinggi bidang ekonomi terbaik di Kota Bogor. brand awareness menjadi salah satu faktor penting yang dibutuhkan untuk memperkuat brand STIE Kesatuan. Sebab, tak bisa dipungkiri bila semakin banyak konsumen yang mengingat brand produk STIE Kesatuan, maka semakin besar pula intensitas konsumsn yang akan masuk ke STIE Kesatuan.

Hal tersebut didukung oleh brand image STIE Kesatuan, sebagai kampus yang antara lain memiliki keunggulan memiliki jaringan yang luas, reputasi yang baik, dan lulusan yang berkompeten,

\section{Minat Siswa SMA dan SMK di Kota Bogor Untuk Melanjutkan Studi}

Minat siswa-siswi SMA/SMK di Bogor untuk studi lanjut ke perguruan tinggi secara umum, juga dianalisis dari sudut pandang motivasi belajar dan status sosial ekonomi orang tua. Sebab kedua hal tersebut mempengaruhi minat siswa dalam melanjutkan jenjang pendidikannya.

Adapun hasil pengolahan data yang masuk dapat digambarkan sebagaimana yang terlihat pada Gambar 3

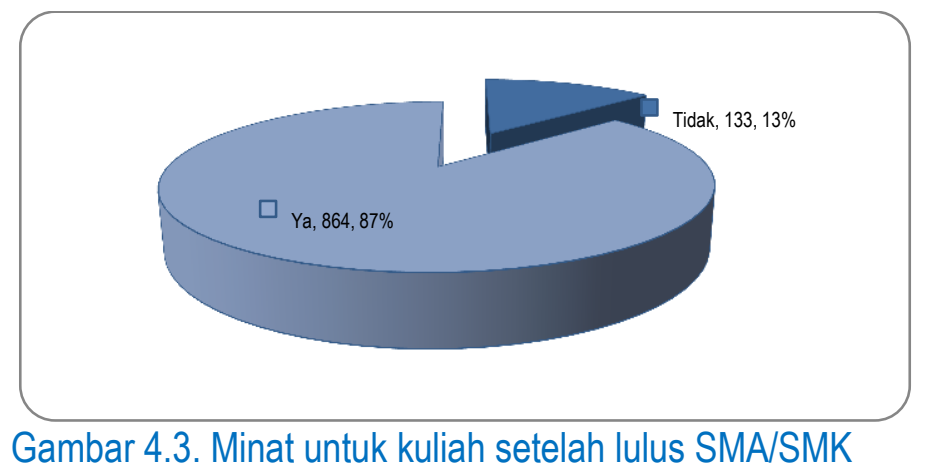

JAS-PT

JURNAL ANALISIS SISTEM PENDIDIKAN TINGG

ISSN $2580-5339$ elSSN $2620-5718$

Volume 2

Nomor 2

Desember 2018

Hal $83-94$

FORUM DOSEN INDONESIA 
Berdasarkan hasil yang tertuang pada Gambar 4.3 dapat diketahui sebanyak 864 responden $(86,7 \%)$ menyatakan berminat untuk melanjutkan studi ke jenjang pendidikan tinggi, sedangkan sebanyak 133 responden (13,3\%) menyatakan tidak berminat untuk langsung studi lanjut setelah lulus sekolah. Adapun alasan yang dikemukakan apabila tidak ingin melanjutkan adalah karena responden ingin bekerja terlebih dahulu dan tidak ada biaya.

Tinggi rendahnya minat siswa-siswi SMA/SMK di Bogor untuk studi lanjut ke perguruan tinggi pada dasarnya dipengaruhi motivasi belajar dan status sosial ekonomi orang tua. Adapun hasil pengolahan data yang masuk dapat digambarkan sebagaimana yang terlihat pada Gambar 4 berikut ini

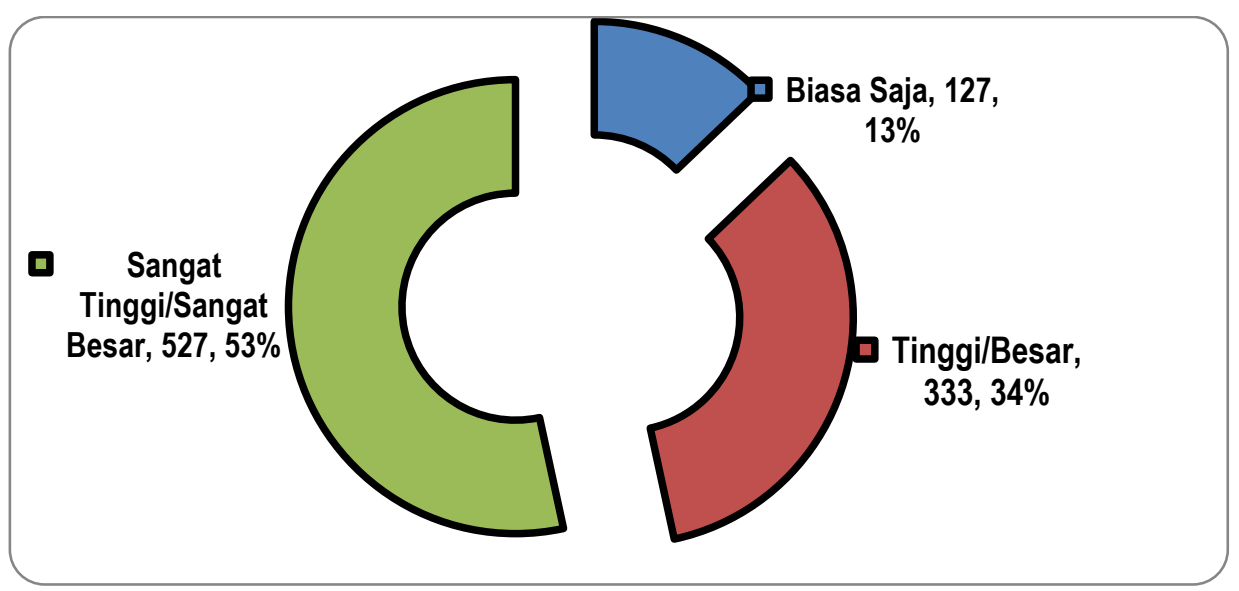

Gambar 4.4. Besarnya minat responden untuk kuliah

Berdasarkan hasil yang tertuang pada Gambar 4.4 diketahui sebanyak 527 responden $(53,4 \%)$ menyatakan sangat tinggi minatnya untuk melanjutkan studi ke jenjang pendidikan tinggi, sebanyak 333 responden $(33,7 \%)$ menyatakan tinggi minatnya untuk melanjutkan studi ke jenjang pendidikan tinggi, sedangkan sebanyak 27 responden $(12.9 \%)$ menyatakan minat mreka biasa saja untuk langsung studi lanjut setelah lulus sekolah.

\section{Jenjang Pendidikan Yang Dipilih Siswa SMA dan SMK di Kota Bogor}

Adapun hasil pengolahan data yang masuk dapat digambarkan sebagaimana yang terlihat pada Gambar 5

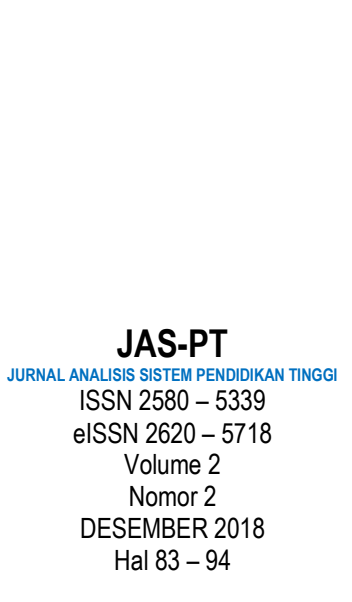

FORUM DOSEN INDONESIA
Sarjana, 863

- Diploma Tiga, 111

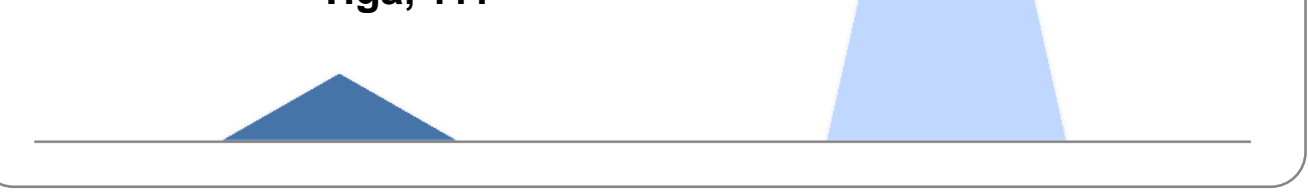

Gambar 5. Jenjang pendidikan yang dipilih siswa SMA/SMK 
Berdasarkan hasil yang tertuang pada Gambar 4.5 dapat diketahui sebanyak 864 responden $(88,6 \%)$ menyatakan jenjang pendidikan yang dipilih adalah jenjang sarjana (S1), sedangkan sebanyak 111 responden $(11,4 \%)$ menyatakan jenjang pendidikan yang dipilih adalah diploma (D3).

\section{Program Studi Ekonomi Syariah Menjadi Pilihan Utama atau Tidak Para Siswa SMA dan SMK di Kota Bogor}

Seiring dengan semakin meningkatnya peran perbankan syariah dan sebagainya, dalam bidang perkonomian di Indonesia, maka kini lebih banyak dibutuhkan SDM di bidang ekonomi syariah Sebagai konsekuensi dari perkembangan ekonomi syariah di Indonesia, kebutuhan akan sumber daya manusia yang menguasai ekonomi syariah menjadi sebuah keharusan. Dibutuhkan sumber daya manusia yang memiliki kompetensi yang tinggi. Oleh karena itu, banyak perguruan tinggi yang membuka program studi ekonomi syariah.

Adapun hasil pengolahan data yang masuk dapat digambarkan sebagaimana yang terlihat pada Gambar 6 berikut ini

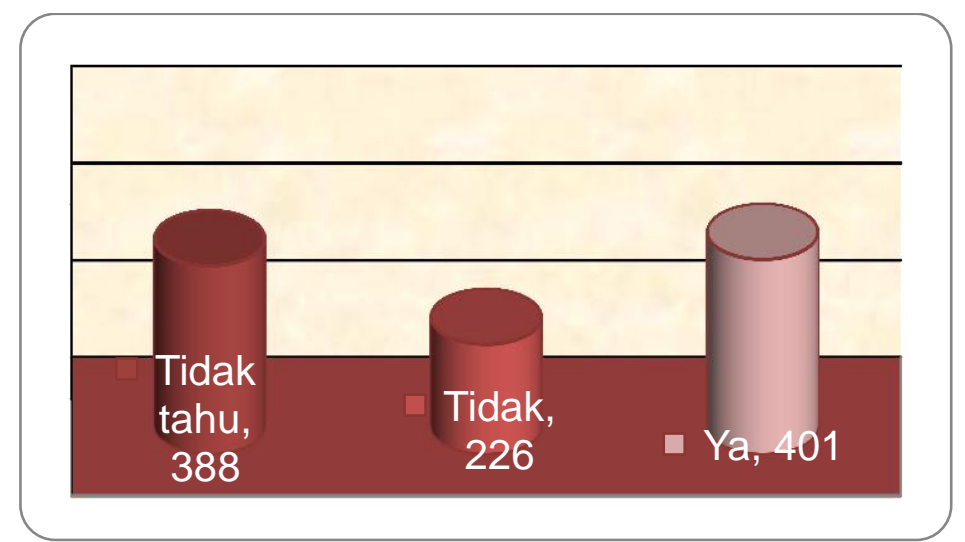

Gambar 4.6. Pengetahuan responden atas jurusan ekonomi syariah

Berdasarkan hasil yang tertuang pada Gambar 6 dapat diketahui sebanyak 401 responden $(39,5 \%)$ menyatakan mengetahui program studi ekonomi syariah, sebanyak 226 responden $(22,3 \%)$ menyatakan tidak mengetahui program studi ekonomi syariah, sedangkan sebanyak 388 responden $(38,2 \%)$ menyatakan tidak tahu berkenaan dengan program studi ekonomi syariah. Alasan utama yang melandasi siswa SMA dan SMK memilih Program Studi Ekonomi Syariah, adalah responden mayoritas ingin mengetahui bagaimana sebuah sistem ekonomi ditata secara syariah.

Pengetahuan siswa SMA dan SMK atas Perguruan Tinggi yang mempunyai Program Studi Ekonomi Syariah

Sehubungan dengan berkembangnya sistem ekonomi syariah, baik di Indonesia maupun di dunia, permintaan terhadap tenaga-tenaga ahli dibidang ekonomi syariahpun semakin tinggi. Oleh karena itu ekonomi syariah juga mulai berkembang pada sektor pendidikan. Perguruan Tinggi diharapkan mampu menjawab kebutuhan sumber daya manusia untuk segala bidang ilmu dalam tataran normative maupun pragmatis, termasuk bidang ekonomi syariah. Saat ini terdapat beberapa perguruan tinggi telah membuka program studi ekonomi syariah.

Adapun hasil pengolahan data yang masuk dapat digambarkan sebagaimana yang terlihat pada Gambar 7 berikut ini

JAS-PT

JURNAL ANALISIS SISTEM PENDIDIKAN TINGG

ISSN $2580-5339$

eISSN $2620-5718$

Volume 2

Nomor 2

Desember 2018

Hal $83-94$

FORUM DOSEN INDONESIA 

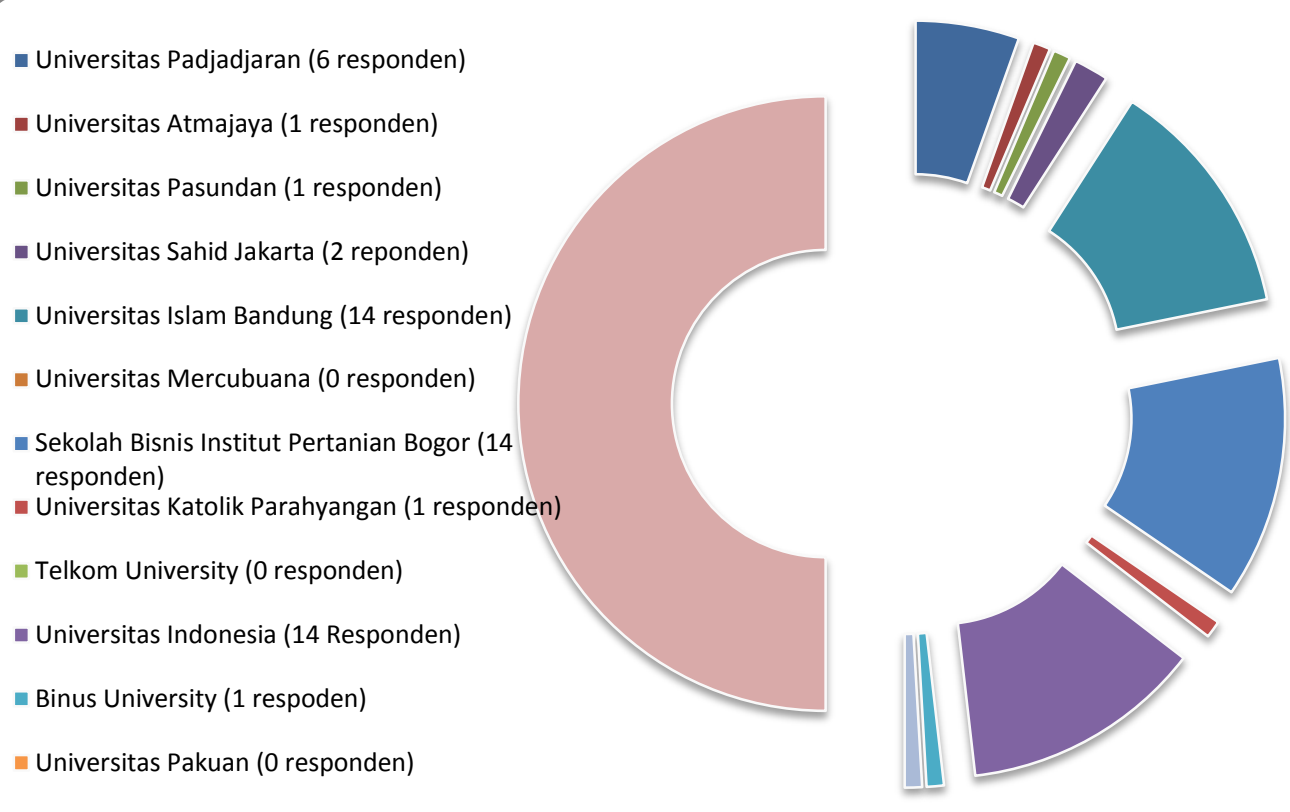

Gambar 7. Pengetahuan responden atas Perguruan Tinggi yang memiliki program studi ekonomi syariah

Berdasarkan hasil yang tertuang pada Gambar 7 diketahui bahwa mayoritas responden siswa SMA dan SMK di Kota Bogor tidak mengisi. Sedangkan responden yang mengetahui perguruan tinggi dengan program studi ekonomi syariah, mayoritas sebanyak 14 responden mengetahui bahwa Institut Pertanian Bogor memiliki program studi ekonomi syariah.

Perguruan Tinggi yang mempunyai Program Studi Ekonomi Syariah, Perguruan Tinggi yang paling diminati siswa SMA dan SMK

Adapun hasil pengolahan data yang masuk dapat digambarkan sebagaimana yang terlihat pada Gambar 8 berikut ini

JAS-PT

JURNAL ANALISIS SISTEM PENDIDIKAN TINGGI ISSN $2580-5339$ eISSN $2620-5718$

Volume 2

Nomor 2

DESEMBER 2018

Hal $83-94$

FORUM DOSEN INDONESIA

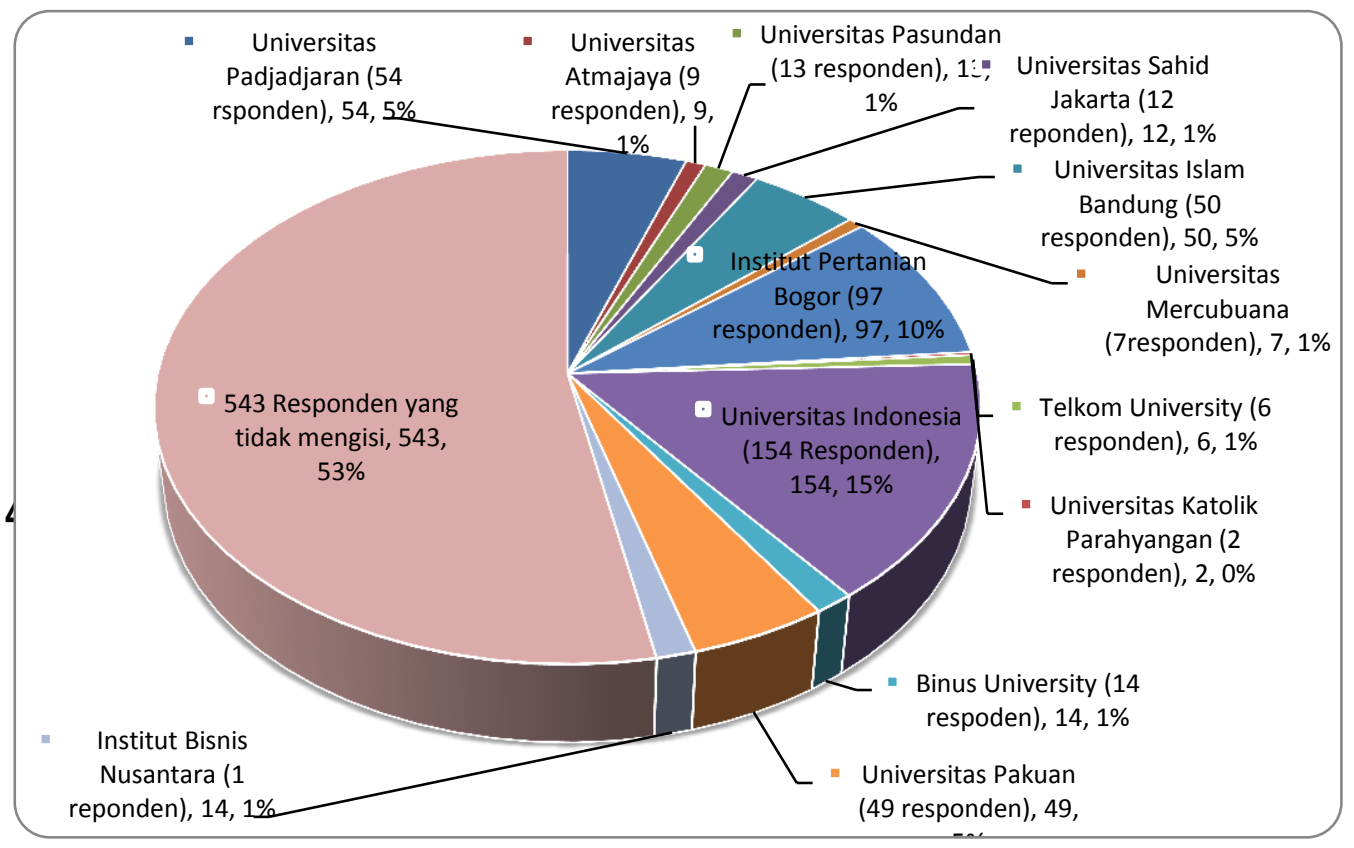

Gambar. 4.8. Perguruan Tinggi dengan Program Studi Ekonomi Syariah yang paling diminati 
Adapun hasil pengolahan data yang masuk dapat digambarkan sebagaimana yang terlihat pada Gambar 10 berikut ini

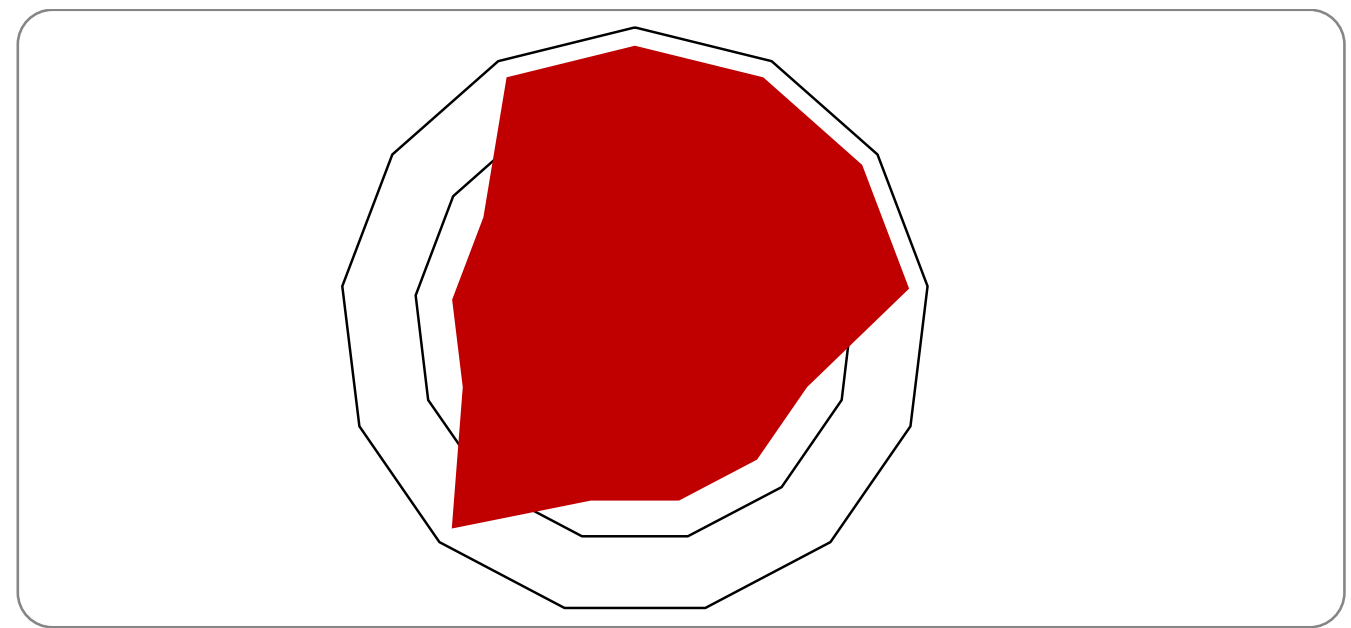

Gambar 4.10 Diagram laba-laba ekspektasi/harapan responden saat diterima/kuliah di Jurusan/Program Studi Ekonomi Syariah

Berdasarkan Gambar 10 di atas dapat diketahui bahwa harapan yang diinginkan Siswa SMA dan SMK ketika diterima/berkuliah di Program Studi Ekonomi Syariah di STIE Kesatuan, lebih banyak pada keinginan responden untuk mendapatkan ilmu dan pengalaman serta keinginan untuk segera lulus dan dapat bekerja.

Berdasarkan analisis SWOT yang dilakukan, dapat dipaparkan sebagai berikut, :

Pertama, Kekuatan (Strength), kampus STIE Kesatuan sedang dalam pembangunan sehingga memungkinkan untuk membuka program studi baru. Sumber daya dibidang ekonomi yang cukup. Menjadikan isu-isu strategi menjadi bahan pertimbangan, seperti arah pembangunan nasional, persaingan nasional, kebutuhan sistem ekonomi penengah, citra kampus ekonomi di Bogor yang sudah mulai dilirik, core value department. Kebutuhan tenaga ekonomi syari'ah yang semakin meningkat dan memenuhi kebutuhan masyarakat.

Kedua, Kelemahan (Weakness), walaupun kampus sudah memiliki banyak ahli ekonomi di dalamnya, tapi tidak banyak dosen yang sudah mengetahui secara mendalam mengenai ekonomi syariah. Kurang siapnya kampus dalam pengembangan, karena membutuhkan pengembangan lain seperti koperasi syariah, bank syariah, dan lain sebagainya. Untuk mencetak entrepreuner syariah. Saat ini pun untuk ruang praktik beberapa program studi pun masih belum terekspose dan tertata secara baik.

Ketiga, Kesempatan (Opportunity), berdasarkan informasi dari http://www.m.republika.co.idd yang diakses tanggal 30 Mei 2018, diketahui bahwa "dalam lima tahun terkhir ini serapan SDM di perbankan syariah naik tiga kali lipat." Itu berarti kebutuhan SDM ekonomi syariah sangat meningkat. Dan ini menjadi kesempatan besar untuk kampus STIE satuan untuk ikut bersaing mencetak tenaga ahli ekonomi syariah.

Keempat, Ancaman (threat), masih terkait informasi dari http://www.m.republika.co.idd dinyatakan bahwa dari 256 perguruan tinggi di Indonesia yang menawarkan ekonomi syariah hanya 8 (delapan) yang berakreditasi $A$, sedangkan 84 berakreditasi $B$, dan 164 berakreditasi C." Sedangkan akreditasi dari BAN-PT kampus ternama IPB untuk prodi ekonomi syariah adalah $B$, Dalam hal ini, berarti untuk program ini sangat

JAS-PT

JURNAL ANALISIS SISTEM PENDIDIKAN TINGG ISSN $2580-5339$ eISSN $2620-5718$

Volume 2

Nomor 2

Desember 2018

Hal $83-94$

FORUM DOSEN INDONESIA 
membutuhkan strategi pengembangan yang baik agar dapat diterima oleh masyarakat dan kampus-kampus ternama yang terkenal dengan kampus islam akan menjadi salah satu pesaing terberat untuk STIE Kesatuan

Berdasarkan analisis SWOT tersebut, maka terdapat beberapa langkah yang dapat dilakukan untuk menjaring mahasiswa baru, dengan mengedepankan dan mempertajam marketing. Dengan berfokus pada empat aktivitas marketing yaitu aktif mengikuti pameran-pameran pendidikan, melakukan periklanan, pemberian beasiswa, dan melakukan jemput bola ke sekolah-sekolah.

\section{KESIMPULAN}

Beberapa kesimpulan penelitian ini adalah :

1. Mayoritas responden mengetahui tentang STIE Kesatuan sebagai sebuah perguruan tinggi yang bagus. STIE Kesatuan sangat dikenal. Hal tersebut didukung oleh brand image STIE Kesatuan, sebagai kampus yang antara lain memiliki keunggulan memiliki jaringan yang luas, reputasi yang baik, dan lulusan yang berkompeten.

2. Minat responden siswa SMA dan SMK di Kota Bogor untuk melanjutkan studi sangat tinggi. Adapun alasan yang dikemukakan apabila tidak ingin melanjutkan adalah karena responden ingin bekerja terlebih dahulu dan tidak ada biaya,

3. Minat responden siswa SMA dan SMK di Kota Bogor untuk melanjutkan studi sangat tinggi.

4. Jenjang pendidikan yang dipilih siswa SMA dan SMK di Kota Bogor untuk melanjutkan studi mayoritas pada jenjang sarjana (S1).

5. Mayoritas responden siswa SMA dan SMK di Kota Bogor, mengetahui tentang jurusan ekonomi syariah.

6. Alasan yang melandasi siswa SMA dan SMK memilih Program Studi Ekonomi Syariah ingin mengetahui bagaimana sebuah sistem ekonomi ditata secara syariah.

7. Mayoritas responden siswa SMA dan SMK di Kota Bogor, mengetahui bahwa Institut Pertanian Bogor memiliki program studi ekonomi syariah.

8. Mayoritas responden siswa SMA dan SMK di Kota Bogor, memilih Universitas Indonesia dan Institut Pertanian Bogor sebagai perguruan tinggi dengan program studi skonomi syariah yang paling diminati

9. Harapan yang diinginkan Siswa SMA dan SMK ketika diterima/berkuliah di Program Studi Ekonomi Syariah di STIE Kesatuan ebih banyak pada keinginan responden untuk mendapatkan ilmu dan pengalaman serta keinginan untuk segera lulus dan dapat bekerja.

Berdasarkan hasil analisis dan pembahasan yang dilakukan, dapat dipaparkan saran sebagai berikut, :

1. Apabila merujuk pada kesempatan yang sangat terbuka lebar, berdasarkan informasi dari http://www.m.republika.co.idd yang diakses tanggal 30 Mei 2018, diketahui bahwa "dalam lima tahun terkhir ini serapan SDM di perbankan syariah naik tiga kali lipat." Itu berarti kebutuhan SDM ekonomi syariah sangat meningkat. Hal ini menjadi kesempatan besar untuk kampus STIE satuan untuk ikut bersaing mencetak tenaga ahli ekonomi syariah.

2. Kampus STIE Kesatuan sedang dalam pembangunan memungkinkan untuk membuka program studi baru. Selain itu memiliki sumber daya dibidang ekonomi yang cukup baik, dan citra kampus ekonomi di Bogor yang baik. Namun dalam hal ini, berarti untuk program ini sangat membutuhkan strategi pengembangan yang 
baik agar dapat diterima oleh masyarakat dan kampus-kampus ternama yang terkenal dengan kampus islam akan menjadi salah satu pesaing terberat untuk STIE Kesatuan

\section{DAFTAR PUSTAKA}

Arikunto, Suharsimi. 2006a. Dasar-dasar Evaluasi Pendidikan. Jakarta: PT Bumi Aksara.

Bimo, Walgito. 2002. Pengantar Psikologi Umum. Yogyakarta: Andi Yogyakarta.

Hadi, Sutrisno.2002. Metodologi Research. Yogyakarta: Andi Yogyakarta.

Kusumah, W. Apakah Minat Itu. Online http://edukasi.kompasiana.com/ 2009/12/16/apakah-minat-itu/

Mardalis. 2004. Metode Penelitian Suatu Pendekatan Proposal. Jakarta: Bumi Aksara.

Mohd Noriah, dkk. Kecerdasan Emosi Dan Hubungannya Dengan Nila Kerja. Jurnal Teknologi, 39(E) Dis. 2003: 77-84.

Munandir. 1996. Program Bimbingan Karier di Sekolah. Jakarta: Direktur Jenderal Pendidikan Tinggi.

Prasetyo, Bambang. 2005. Metode Penelitian Kuantitatif : Teori dan Aplikasinya. Jakarta: PT Raja Grafindo Persada.

Pratiwi, Wulandari. Universitas Negeri dan Jurusan yang paling diminati. Online http://community.gunadarma.ac.id/archive/mod_blog/id_9808/title_tugas-1-risetakuntansi-penelitian/

Ahmaediansyah, R., 2018. PENGARUH PEMASARAN RELASIONAL, KEPERCAYAAN, KEDEKATAN EMOSIONAL TERHADAP LOYALITAS PELANGGAN (Studi kasus BOLT 4G LTE).

Siagian, P Sondang. 1995. Teori Motivasi Dan Aplikasinya. Jakarta: PT Rineka Cipta.

Utami. 2007. Faktor-Faktor Yang Mempengaruhi Minat Berwiraswasta (StudiDeskriptif Pada Usahawan Rental Komputer Di Sekaran Gunung Pati Semarang). Skripsi: Universitas Negeri Semarang.

Slameto. 2003. Belajar dan Faktor-Faktor yang Mempengaruhinya. Jakarta Rineka Cipta.

Sudrajat. $\quad$ A. 2008. Teori-Teori Motivasi. Online http://akhmadsudrajat.wordpress.com/2008/02/06/teori-teori-motivasi.

Sugiyono. 2007. Statistika Untuk Penelitian. Bandung: Alfabeta.

Sujdana. 2002. Metoda Statistika. Bandung: Tarsito.

Sukardi. 2003. Metode Penelitian Pendidikan Kompetensi dan Prakteknya. Jakarta: Bumi Aksara.

Sofyan, A. 2009. Tiga Motif Ber-HMl. Online http: //bermenschool.wordpress.com/2009/03/06/tiga-motif-ber-hmi/

The Liang Gie. 1994. Cara Belajar yang Efisien. Yogyakarta: PUBIB (PusatBelajar Ilmu Berguna). IImu Berguna).

Vivipermata. 2008. Apa Itu Minat. Online http://vivipermata.blog friendster.com2008/08/28/

Zuriah,Nurul. 2009. Metodologi Penelitian Sosial dan Pendidikan. Jakarta: PT Bumi Aksara.

http://www.ipb.ac.id diakses tanggal 11 April 2018

http://www.pengertianpakar.com diakses tanggal 11 April 2018

www.aasi.or,id diakses tanggal 11 April 2018

JAS-PT

JURNAL ANALISIS SISTEM PENDIDIKAN TINGGI

ISSN $2580-5339$

eISSN $2620-5718$

Volume 2

Nomor 2

Desember 2018

Hal $83-94$

FORUM DOSEN INDONESIA 
www.agustiantocentre.com diakses tanggaal 11 April 2018

www.arthamadani.co.id diakses tanggal 11 April 2018

www.asianbrainhippo.com diakses tanggal 11 April 2018)

www.asuransibank.com diakses tanggal11 April 2018

www.ban-pt-universitas.com diakses tanggal 11 April 2018

www.bi.go.id diakses tanggal 11 April 2018

www.business-law.binus.ac.id diakses tanggal 11 April 2018

www.ekonomisyariah.org diakses tanggal 11 April 2018

www.forumekonomisyariah.org diakses tanggal 11 April 2018

www.iaei.org diakses tanggal 11 April 2018

www.ifsa.or.id diakses tanggal 11 April 2018

www.islamic-economics.uii.ac.id diakses tanggal 11 April 2018

www.kemenkeu.go.id diakses tanggal 11 April 2018

www.mediaasuransinews.com diakses tanggal 11 April 2018

www.republika.com 7 April 2016 diakses 11 April 2018

www.thesis.umy.ac.id diakses tanggal 11 April 2018

www.wikipedia.com diakses tanggal 11 April 2018

\section{JAS-PT}

JURNAL ANALISIS SISTEM PENDIDIKAN TINGG

ISSN $2580-5339$

eISSN $2620-5718$

Volume 2

Nomor 2

DESEMBER 2018

Hal $83-94$

FORUM DOSEN INDONESIA 